\title{
Mary Wilcox Silver
A Woman Pioneer in Oceanography
}

The Woods Hole Oceanographic Institution Women's Committee initiated the Woman Pioneer in Oceanography Award in 1994 as part of a Women's History Month celebration. Past awardees have included Mary Sears (1994), Betty Bunce (1995), Ruth Turner (1996), and Marie Tharp (1999). In 2002, Mary Wilcox Silver was honored as the first recipient of the Woman Pioneer in Oceanography Award named for Mary Sears. The award goes to: "A woman who has provided significant scientific leadership in understanding our marine environment and has provided inspiration and/or opportunity for other women in marine sciences. The intent is to recognize long-term, lifetime achievement and impact. Special consideration should be given to candidates who also have shown leadership through mentoring junior scientists, technicians, or students." This article is based on the presentation given by Mary Silver when she accepted the first Mary Sears Woman Pioneer in Oceanography Award.

When I prepared for the original oral presentation and, more recently, this article, I considered either discussing the history of my research career as a scientist who started her career in oceanography in the early 1960s or presenting a more personal history of my experiences and views that reflected my life as an academic. I have chosen the second and more personal path, weaving in some details of my research.

When I was a child growing up in San Francisco, I was very much aware of the sea. Occasionally my family would go to the main beach, which faced the open North Pacific, and my brother and I would argue about where the waves came from. Even at my house several miles away, I was aware of the sea because - with the right wind direction-I recognized the smell of massive numbers of beached Velella (the "sailor by the wind" jellyfish) or decomposing seaweeds. I also was fearful of the sea: my early nightmares were often about giant tsunami waves that washed away my home and swept us away. By the time I was in high school, I understood that I would be a biologist and that I wanted to be a naturalist - that is, to understand the physical world as I saw it. But I also wanted to have a family, too, and I just assumed I could be both a scientist of some sort and have children.

I grew up in a family that had great respect for education and science. My father, who had begun his career as a land surveyor, was especially interested in geology and mathematics. My sister wanted to become a chemist and my brother a physicist, decisions we made fairly young. All of us became scientists and worked more or less in these areas. It was probably my mother's influence that actually encouraged me to be a naturalist and a field-oriented scientist. My mother never finished elementary school, having grown up on a relatively poor farm in North Dakota, though she subsequently received a secretarial degree that allowed her to move westward as a young woman and find a job, far from home. She taught me a love of nature, and as a child, would take me into our yard or on field trips and bring along her field guides for flowers, butterflies, or other organisms that she found interesting. My mother was also a very courageous woman, having been the first in her family to leave North Dakota, to take the train alone as a young woman to the woods of Oregon, where she began her new life as a secretary in a logging camp where there were few other women. Through-

Mary Wilcox Silver (msilver@ucsc.edu) is Professor, Ocean Sciences Department, University of California, Santa Cruz, CA, USA. 
Remarks by Dr. Robert Gagosian, Director, Woods Hole Oceanographic Institution, at the Mary Sears Woman Pioneer in Oceanography Award ceremony held March 28, 2002.

Good afternoon everyone, on this absolutely gorgeous Cape Cod afternoon. I'm really truly honored to welcome you and I'm also very proud-and I want to emphasize the word proud - to participate in this presentation of the first Mary Sears Woman Pioneer in Oceanography Award. The speakers who are going to follow me will provide you with the history of the award, and specifically, describe the incredibly difficult job the selection committee had in the whole process in coming up with a recommendation for our inaugural awardee. On the occasion of Mary Sears's eightieth birthday, the editors of Deep Sea Research dedicated an entire issue to her. And I believe their assessment of Mary's career really said it all. There's one statement I would like to share with you. "Mary Sears has probably played a greater role in the advancement of oceanographic studies than any other woman." I think that's an extraordinary statement. The statement, I might add, was echoed in November of 2000 with a very loud splash down in Pascagoula, Mississippi when the Navy's newest hydrographic ship, the USNS Mary Sears, was launched. For those of us who were there, it was really a very special moment.

Now another Mary is being recognized for her tremendous impact on the field of oceanography. Like Mary Sears, Dr. Mary Wilcox Silver has been a true pioneer in many respects, first and foremost as a scientist. She was a pioneer in a traditionally male-dominated field (no longer that way, but certainly traditionally). Mary Silver is also being recognized for mentoring junior colleagues in an extraordinary way - and, I might add, she has been an inspiration to junior and senior scientists alike. To me, she is the absolute perfect choice of setting the bar and the highest standards for this award. I personally couldn't be more delighted with the choice. Now, I'd like to turn the program over to Dr. Deborah Smith. Debbie is a senior scientist in our geology and geophysics department, and she's going to provide some background to the award. out her life, she was a fighter for the underdog, a hard worker and a believer in the strength and rights of women.

As a young girl, I went to a series of parochial schools, places not necessarily favorably disposed towards women having careers other than typical feminine options of the 1950s and clearly not promoters of science. I remember writing a biology paper in my high school on evolution and natural selection, which was viewed as slightly heretical, though informative. My high school teachers warned me, when I discussed entering the University of California at Berkeley, that it was a "godless" school where I would lose my religion and the value system I had been taught. Indeed, my perspectives were radically altered when I entered Berkeley, and a world of previously unknown options and ideas opened before me.

Part of my decision to attend UC Berkeley arose out of a previous experience in a science club. I felt a misfit in my high school and my mother, likely understanding this, encouraged me to attend the "student section" of the California Academy of Sciences, a wonderful natural history museum with its associated Steinhardt Aquarium. The student section (later called the "junior academy”), a science club for high school students, was run by staff members of the Academy. We met at the Academy and went on field trips with staff experts, trips that exposed us to the organisms that were the subject of study and display at the academy - experts who were herpetologists, invertebrate biologists, botanists, and so on. On our weekend field trips, I remember crawling around on my knees in the tide pools with friendly, 
knowledgeable experts who pointed out how barnacles filtered water and who told us the species names and interesting facts about the organisms we encountered. We also explored caves, watching bats hanging upside down, and visited local forests. The trips were eye opening. I also encountered other girls and boys who were more like me than those at the schools I had attended: basically I felt I "belonged" in the group.

As a beginning undergraduate at UC Berkeley, I expected to become a field scientist of some sort, possibly a marine biologist. But once I began my college major, I was swept up in the excitement of new and developing areas of biology or ones about which I previously knew very little. One area was neurobiology and the other, which was related, was animal behavior. I had the good fortune to take a class from an inspiring instructor on animal behavior, Dr. Peter Marler. I then completed an undergraduate research project with him, recording the courtship "songs" (viewed on the oscilloscope) of the fruit fly Drosophila, and I decided I wanted to become a neurobiologist, studying the underlying neural basis of behavior. The thesis project convinced me that I wanted to be a researcher.

After completing my undergraduate degree, I took a year off to "expand my horizons" beyond science, planning to study philosophy or history, to gain language skills, and to relax after working hard as an undergraduate. I went to the lovely medieval University town of Tübingen in Germany, where I actually took a rather heavy curriculum in animal physiology for the first semester. After than, I proceeded mostly to travel alone or with young people I met along the way and to have many adventures around Europe. The traveling and the difficulties I sometimes encountered (and usually resolved), gave me a sense of my own personal strength and ability. During this time, I applied to Cologne, in Germany, to enter a Ph.D. program and study animal behavior and neurobiology. But I also had the freedom and time to consider much more seriously what I wanted to do as my life's work. And during that time, I recalled my California Academy experience and how much I loved the sea, and then realized that I was choosing the wrong direction. A former roommate from Berkeley had spoken often about Scripps Institution of Oceanography, where her father was a chemist, telling me about the excitement of the field and praising the institution. I quickly applied to the Scripps doctoral program. By that time-after a year abroad-I was becoming homesick, so I declined the offer of acceptance I had received from Cologne and chose Scripps, when a letter arrived offering entry into the doctoral program in California. me-very supportive. He gave me just the right amount of guidance (i.e., provided initial direction for my research, but let me mostly work out the details), got me involved in seagoing operations, and stepped in and helped me when I found myself in trouble. (One difficulty, which he and another committee member, Mike Mullin, helped resolve was related to a problem I encountered with the mode of questioning used during my doctoral qualifying exam: Mike and John's resolution of the dilemma was key to my remaining in the Ph.D. program.) As a student starting in an oceanography program in the early 1960s, I did not find the overall climate for women entirely encouraging, a situation I later learned was experienced by some women students at other oceanographic institutions at that time. Indeed, shortly after I entered the program, there was discussion by the higher administration of excluding women students from the oceanography program because our failure rate supposedly had been high. I was told that women were not completing their

\section{As a student starting in an oceanography program in the early 1960s, I did not find the overall climate for women entirely encouraging.}

Entering Scripps, I was assigned an advisor, Dr. John McGowan, presumably because of a match of interests that I had expressed in my application letter, and this association led into the career that I have today. John was a fine teacher, an expert on zooplankton ecology and large-scale oceanographic phenomena, and-importantly for degree and that we were taking the place of people who needed to be there more, that is, our male colleagues.

When I entered Scripps in the mid 1960s, I did notice that there were few established women oceanographers in senior positions. It was a fact of life and, though obvious, did not discourage me. I wondered, however, how a woman 
would manage her life as an oceanographer, especially if she were to have a "normal" life with children, as did most of the male scientists at the institution. There was one female researcher on the staff who was enormously kind, wise, and supportive of me, and to whom I occasionally told my troubles: Marnie Knight, an expert on krill. Marnie clearly loved her work, sometimes advised me on practical matters in the lab, and encouraged me. There was also an accomplished woman graduate student in biological oceanography one year ahead of me, Elizabeth Venrick, and she was clearly doing very well and heading for a successful career in oceanography. There were also a few women who started out in my year class and a few in the year classes ahead of me, but we represented a relatively small percentage of the oceanography student body. I discovered later, in fact, that there had been several women who previously had successfully completed the oceanography Ph.D. program at Scripps, one of the first being Dr. Easter Allen Cupp in 1934, and later Dr. Betty Bowden, whom I encountered as a graduate student. But there were no women faculty who were oceanographers and no women Ph.D.s in my area on the staff at the institution, though there was at least one other woman Ph.D. in another marine discipline when I was a graduate student. I also learned that many women had worked as technicians on oceanographic vessels in the past, though not as lead principal investigators, and that there had been previous intervals when women apparently were not encouraged to work at sea nor encouraged to obtain advanced degrees in oceanography.
My major initiation into oceanography was the experience of going to sea on Scripps research vessels. John McGowan had suggested I work on the ecological importance of salps as primary consumers in the California Current, and study of the living organism required collections at sea, as salps only rarely come near the coast. As I began my field research, an opportunity to take samples on a research cruise when ship time became available on the small R/V Ellen $B$. Scripps-a cruise formerly dedicated to another project. To my amazement, I was appointed chief scientist on the cruise, was the only woman aboard, and, years later, learned that I was one of the earliest female chief scientists on a Scripps vessel. It was an incredible adventure. Shortly after we left port, we encountered galeforce winds, and there were awe-inspiring, short-period 20-foot swells in the southern California Bight where we were collecting salps. We survived the cruise, though I still recall howling winds, difficulty walking on the deck, and my being inspired by the power of the sea. But, equally memorable was an experience with the crew of the ship, with whom I was on good terms and often chatted. In particular, I remember a request from the cook: would I mend his trousers, which were ripped? Since the crew was helping me with my work and I considered them friends, it was difficult for me to deny the request: I did the mending, though with a great sense of both the irony and the humor of the situation! It now appears to me to be a reflection of those times, that - as a chief scientist—I should be asked to perform "womanly" chores of mending, even though I was in charge of the research operation. Shortly after we returned from sea, personnel in ship operations chided me. They asked, "Where did you sleep on the vessel?" And I said: "Well, I slept in the bunk room." The response was: "There's only one science bunk room. Did you sleep there with the men?" My answer was not well received, but it was clear there was no other place to sleep-another dilemma of the time! On the day boat where I normally did my salp collections, however, being a young woman oceanographer was less controversial. My tasks were much more stereotypical for an oceanographer-I learned how to run the winch, handle the nets, and operate gear, as there was only one crew member (the captain) and myself. These experiences at sea while a student gave me considerable confidence when I left the institution to work in an environment with fewer sea going facilities.

By the time I finished my Ph.D. at Scripps, I had gotten married to another oceanography student. He completed his degree and got a job before I did, and like many spouses, I followed my husband to the area where he received a position, which was in the San Francisco Bay area. With the help and recommendation of my advisor, John McGowan, I was able to contact an investigator at Moss Landing Marine Labs (MLML), who subsequently provided my first post- doctoral position, which was a temporary research position working with graduate students on a Sea Grant project. A full time faculty position open up shortly at MLML. Luckily I obtained that position, to a great extent because of the strong support of the MLML graduate students, who vouched for my teaching ability and lobbied strongly that I be allowed to interview for the position. About a year later, I obtained an 
academic position in the University of California's new campus at Santa Cruz, a position I sought particularly because it reduced the combined commuting distance for my husband and myself from our home. Starting with that position, the first academic appointment in the marine institute at UCSC, I have now been a professor for 33 years on the campus and calculate that I have taught over 8000 undergraduate students, including many successful ones whom I regularly encounter at professional meetings! The campus was (and still is) socially progressive, and my ocean science department has been wonderfully supportive, with a departmental ratio of $1: 1$ ratio of female to male faculty, a truly extraordinary ratio for an oceanography department.

Personal connections among professionals have been a very important part of my advancement and satisfaction as a scientist. I think particularly of the importance of my thesis advisor and a few other faculty at Scripps who encouraged me, helped me professionally navigate some troubled waters as a graduate student, and set up the initial contacts that led me to my first job. At the time I graduated, I was not particularly well connected in the field with young scientists because I had not attended many professional meetings (though that may have been the case with many graduates at the time). However, I did have connections with other graduate students who attended Scripps around the same time. For instance, Charlie Miller, now a long time faculty member at Oregon State University, provided an invaluable opportunity for me: Charlie recommended me as a biological oceanography panelist at the National Science Foundation
(NSF) to review grant proposals. Prior to that time, I had written several unsuccessful and, retrospectively, rather poor proposals. But once I participated on the review panel, I understood what was needed to write a good one. That was another turning point in my career. Another UCSC colleague, a marine ge- over a decade of funding for my marine snow research. Meanwhile, I began to encounter women scientists, younger than me, who were coming through the system and with whom I naturally felt strong affinities, both as research colleagues and friends. These included Alice Alldredge, who has been inspirational

\section{In particular, I remember a request from the [ship's] cook: would I [the chief scientist] mend his trousers, which were ripped?}

ologist from Scripps, gave me additional helpful advice. He suggested I could negotiate with a granting agency: that notion was revolutionary to me. At the time, I was beginning to study marine snow, and the phenomenon was basically unknown and of uncertain significance. No agency appeared willing to fund research on the topic, though a supportive senior researcher at Scripps (a former member of my thesis committee) suspected the particles were important and helped me get started by providing a few thousand dollars in university monies to acquire some samples. My UCSC colleague also urged me to put in a proposal to NSF, and-even though it might not be funded-perhaps I could negotiate a very small allocation of start-up money. Then, he suggested, with some initial interesting data, I could return to NSF to request a continuation proposal, which might position me more favorably for funding. So I took his advice and managed to negotiate a very small amount of exploratory funding, which subsequently led to a full proposal, which then led to to me and a model academic and scientist at the University of California, Santa Barbara, and Peggy Delaney, the next-hired woman in my department at UCSC, who has become an exemplary academic, and a wise advisor and mentor to me (as I hopefully was to her, earlier in her career). My scientific connections with other women oceanographers are many and I often joke that we now, after sufficient years, have a true "old girl's club," a network that helps us as well as our students, male and female, in navigating the field. (For me and other women, this network coexists, amicably, with a network of many male oceanographic friends and colleagues.)

Always I had expected to have children and a full family life, as well as a meaningful career. Unfortunately, I had few female models to follow as I entered the field of oceanography or even among the women on the faculty at that time at UCSC. My first child arrived at a difficult time in my career: as I approached the academic tenure review. My daughter's birth, which was a joyous event for me, 
came when I was beginning my marine snow research and when I had just received notice from the administration that I needed to accelerate my research productivity if I were to obtain tenure. In response, a senior mentor at UC Santa Cruz, Dr. Bill Doyle, director of the marine science center, helped arrange teaching relief and one-year of assistance from an accomplished microscopist (Dave Ringo) who taught me the tools especially if one wants a rich personal life with committed relationships and with children. I have spent a good deal of time speaking with students and young colleagues about these dilemmas. In fact, my early career was probably slowed by such discussions, a time when there were few professional women "role models" available to speak with the many young women who sought advice on these issues. I think now there are many more coping

\section{Students have played a key role in my enjoyment of the field, my continued learning, and even my survival as an academic oceanographer.}

of electron microscopy, initiating my research on microorganisms that colonize marine snow. Then my son arrived, with the attendant dilemmas of childcare and a more intense need for balancing family and career. With these increased family demands, I simply had to reduce the time used for class preparation and other departmental tasks. Surprisingly, I discovered that I could spend much less time on some of these, especially my teaching, without greatly affecting the quality. During this time, I also consulted a women faculty member in the astronomy department at UC Santa Cruz who had children and been quite successful. I subsequently found that each woman of that time who was an academic and field scientist had developed very personal and individual solutions to balance family with academic and research needs. None of us were entirely happy about the solutions, but they worked!

Difficulties still exist today, I believe, for women to successfully navigate lives as an academic and an oceanographer, strategies for balancing career and family than I had. Unfortunately, I still hear very talented young women questioning whether it is possible to have a career in the field and a family, Interestingly, I have never had a young man ask me about this dilemma, though I advise many. These are prime issues our field must address to bring women into full membership in the oceanographic community.

One topic I sometimes discuss with my academic colleagues is the issue of tenure and the "clock" phenomenon. The problem is that women have several clocks: the tenure clock, the childbearing clock, and our partner's clock (if we have a partner). Clearly a woman's biological clock requires children by the time we are in our 30s or early 40s. But, this is the time we often reach tenure deadlines if we follow the typical course of an academic career. Many women academics, as did I, still take the main responsibility of organizing household events, including childcare, roles that place heavier responsibilities on them than a male partner. If motherhood begins near tenure time (as it did in my case), time demands from family can appear almost overwhelming. But I believe there are solutions to the clock issues for women in oceanography, but that we must look elsewhere for them, since historically there have been too few women to press for solutions in our field. We need to look to workplaces where there have been strong incentives to retain women, for example, in progressive business environments where retention of highly trained and well-qualified women is critical and where considerable thought, effort and-most likely-money has been committed to finding solutions. I suspect that, in such environments, creative solutions have been found for dealing with key issues such as childcare, time off for nursing mothers, as well as provisions for fathers to take time off for childcare, solutions that allow women to continue productively in their professional careers. Some progressive university departments indeed have already attained most of these goals.

When I think of my life as an oceanographer, my experience at sea has been critical. My experience of true membership in the oceanographic community came with participation in the NSF- sponsored VERTEX program in the 1980s. This interdisciplinary project focused on the quantitative exports of organic particles from the ocean's surface layer and their remineralization in underlying waters. My contribution was the analysis of marine snow as a contributor to the flux and the biological origins of the sinking material. The project involved researchers from a variety of oceanographic disciplines and a number of memorable annual cruises. 
By participating in the project, and especially by going to sea (and being a chief scientist on one of the legs), I felt for the first time that I really belonged in oceanographic community and had a contribution to make. I remember leaning against a bulkhead and chatting about research at length with John Farrington, for whom I had great respect, and experiencing a sense of membership in the oceanographic community. The VERTEX researchers were an impressive group-John, Bob Gagosian, Cindy Lee, Stu Wakeham, Ken Bruland, Dave Karl, George Knauer, and others, and we were led by John Martin. I have recently been reminded, on a recent NSF-sponsored VERTIGO cruise, about the importance of such conversations with other researchers and with students while waiting for samples to be brought aboard or while sitting in the galley after a hard day of work: the seagoing experience is a "primary" one in our careers, with an intensity not easily matched ashore. The conversations often cut across ranksyoung students and technicians talking with seasoned, senior researchers, providing invaluable connections for all of us, connections that last long after the cruise is over. Furthermore, I believe that going to sea and experiencing the difficulties of collecting data give a muchneeded perspective on our data. How can we interpret our results if we do not know what might have gone wrong when our data were collected? Such an experience is one of the reasons why women need full membership in the community of seagoing oceanographers.

Historically, there has been substantial impediments to women going to sea, and the remnants of this history are largely, but not entirely gone. The restrictions,
I suspect, go back in seafaring cultures for centuries if not millennia. My recent sabbatical experience in islands off Tanzania reminded me of the phenomenon: men went to sea to fish (often on dangerously small boats), whereas women, sometimes with their children, harvested seafood presumably more safely along the shoreline. There is a long history in the United States (and in most countries, I suspect) of women's limited participation in seagoing operations and, until the last several decades, of women at sea on vessels with military connections. Since many of the US oceanographic vessels were funded by the Navy and followed naval traditions (which largely excluded women from seagoing duty), women consequently were normally not welcome aboard until the last several decades. As I entered the field in the 1960s, some of these exclusionary traditions still were in evidence. In some cases, the traditions limiting access at sea now seem relatively trivial or at least resolvable, for instance, bunking arrangements and "heads" (bathroom facilities) on ships that need to be separate for men and women. An older notion still survives in places, especially with the crew: women are bad luck on ships, a belief my women students and I have sometime encountered. There are other more subtle and difficult issues, which I still hear after many decades. A not uncommon complaint among young woman oceanographers is the need to substantially alter their demeanor and behavior at sea because behavior considered normal on land might be perceived as inviting romantic advances from the crew. This problem is especially evident on long cruises where there are frequent contacts between women researchers and a crew that often has very few women among its own membership. Frequent encounters in limited quarters can make interactions very strained indeed if one of the parties is uncomfortable with the contact. One simple solution is to "dilute" the gender imbalance by having a higher percentage of women in the ship's party, so that the combined numbers of female crew and female scientists more closely approached the number of males aboard.

Students have played a key role in my enjoyment of the field, my continued learning, and even my survival as an academic oceanographer. For instance, my work on marine snow began with two bright young undergraduates, Jon Trent and Alan Shanks, in my undergraduate biological oceanography course in the 1970s. These two often asked questions in class that I had difficulty answering, a very uncomfortable situation when presenting material as the authority on a subject! But those questions led to more discussions among the three of us and eventually to the design of undergraduate student research projects for Alan and Jon: this field work led into marine snow research that the three of us did together at UCSC, a joint paper in the journal Science, and to later projects by the two as doctoral or postdoctoral researchers elsewhere and to my own subsequent marine snow work. I early recognized that they and other students who sometimes made me look foolish, instead, could be a blessing, because they forced me to see contradictions that existed in the material I was presenting, factual material that was indeed contradictory but represented the present state of knowledge in the field. I have come to recognize that if one has the courage to listen, or to argue respectfully with thoughtful students, one may learn a 
great deal and even discover new areas to explore, as I did with Jon and Alan. I also have had a good number of wonderful graduate students who have led my research into new directions, done extremely creative work, and become personal friends and continuing colleagues over the years, former students like Dave Garrison, Tony Michaels, Marcia Gowing, Debbie Steinberg, Kathi Lefebvre, Sibel Bargu, and many others.

A major difficulty that I have had throughout my working life is one of balancing multiple professional activities at the same time and remaining on track as a researcher. One set of concerns is the balance among activities required to be a responsible and effective teacher as well as a contributing member of the academic unit, while keeping a research career current and funded. At UCSC there are still relatively few oceanographers (a total of one to nine over my career, and a long-term average of about five). With such a small group it would have been easy to lose an overview of the field of oceanography, especially since my institution lacked campus access to facilities found at larger oceanographic institutions. I was extremely fortunate, however, to have been appointed an adjunct member of the Monterey Bay Aquarium Research Institute (MBARI) since its establishment in the late 1980s. By visiting that facility once a week now for nearly 15 years, by being treated generously and hospitably by the staff and administration (e.g., given a "visiting scientist" office), and having the opportunity to compete for access to their seagoing facilities (e.g., ships and remotely operated vehicle [ROV] use), I have been had advantages expected of researchers at large US oceanographic facilities like Scripps Institution or Woods Hole Institution. Through this access my research possibilities have expanded: first by gaining access to sophisticated visual tools to study marine snow down through the water column (using a MBARI-engineered optical device mounted on a ROV) and more recently to begin a time series on harmful algal bloom (HAB) species, an area of research that is now the main focus of my research. Through MBARI, I have acquired five years of nearly weekly offshore samples, collected by crew of the day boat, the R/V Pt Lobos, for HABS in Monterey Bay. Additionally, my MBARI connections have led to very productive research interactions with other oceanographers at the facility, starting with Cindy Pilskaln (joint work on marine snow), to studies of regional plankton ecology with Francisco Chavez, and most recently to collaborative $\mathrm{HAB}$ work with Chris Scholin, all interactions that would never have occurred without membership in the MBARI community.

Looking back at a career that began as a graduate student over 40 years ago, I am deeply grateful to have found a calling that has offered me such a full, exciting, and satisfying career. There are some important themes in my personal history, as I look back. I have been mostly an optimist and subsequently been willing to take risks in selecting research directions that I "knew," somehow, would be interesting and worthy of attention. These risks include my decision to work on marine snow after I had done some initial microscopy studies on these thenpoorly known particles, and my choice more recently to look at the much more applied research area of HABs and the cascade of their toxins through coastal food webs. My perspective as a researcher was very much affected by my teaching, which required that I develop courses on very broad topical areas, which then allowed me to move into areas far from my original training. I especially have been helped by my students, who over the years enriched my intellectual life, fought at critical times for me, led me into new areas, and helped me to become a better, more versatile scientist. I have been fortunate in having many mentors, originally mostly men but increasingly women, who offered solutions, inspired me, and taught me how to navigate through difficult straits and a department that was truly extraordinary. I have been supported by a network of friends who helped me through difficult times in my career and personal life, keeping me going when I might otherwise have left the field for an easier path. But even well before my career began, I had a family that gave me a lifelong set of values, with a strong and principled mother willing to fight for what she believed. And I have been especially blessed by being able to raise a family with children of whom I am extremely proud and who, as they have entered adulthood, show me that I did not do this balancing job too badly: to attain a life goal of both a close family and a rich and satisfying career as a woman in oceanography. 四 